\title{
Wie dramatisch das ist, verrät die Sonografie
}

\section{Der 34-jährige bisher gesunde Mann beklagte seit zwei Wochen bestehende Halsschmerzen, Schlappheit und leichtes Fieber.}

— Die körperliche Untersuchung ergab unauffällige Befunde von Cor und Pulmo, einen leichten Druckschmerz im linken oberen Abdomen bei unauffälliger Peristaltik, Temperatur rektal $38,2^{\circ}$ und bei der Inspektion des Pharynx multiple, disseminierte Stippchen im Tonsillenbereich. Bei der wegen der Verdachtsdiagnose einer Mononukleose durchgeführten Blutabnahme zeigte sich ein ikterisches Serum, im Urin fand sich ein deutlicher Urobilinogennachweis.

Die Laborwerte am Tag darauf zeigten einen positiven EBV-(Epstein-Barr-Virus-)AK-Nachweis; Leberwerte, Bilirubin und LDH waren erhöht bei Lymphozytose im Differenzialblutbild; deutlich erniedrigt waren $\mathrm{Hb}$, Erythrozyten, $\mathrm{MCH}$ und $\mathrm{MCHC}$.

In der zusätzlich noch durchgeführten abdominellen Sonografie ergab sich der in der Abbildung dargestellte Befund.

Mit der Verdachtsdiagnose Milzblutung bei einer schweren hepatisch-ikterischen und hämolytischen Verlaufsform einer Mononukleose wurde der Patient in das nächstliegende KH eingewiesen, wo er zunächst konservativ mit der Gabe von Erythrozytenkonzentraten behandelt und sein Kreislauf stabilisiert wurde. Nach zehn Tagen wurde er wieder entlassen. In den bei uns durchgeführten sonografischen Kontrollen zeigte sich jedoch im weiteren Verlauf eine Progredienz des Milzbefundes, sodass eine erneute Einweisung zur dann durchgeführten operativen Sanierung des Milzkapselrisses notwendig wurde. Der anschließende Erholungsprozess verlief komplikationslos. Wieder arbeitsfähig wurde der Patient aber erst nach insgesamt acht Wochen.

Die Hauptdifferenzialdiagnose der akuten Mononukleose ist die akute Streptokokkenangina, die eine antibiotische Behandlung notwendig macht, jedoch bei Vorliegen des

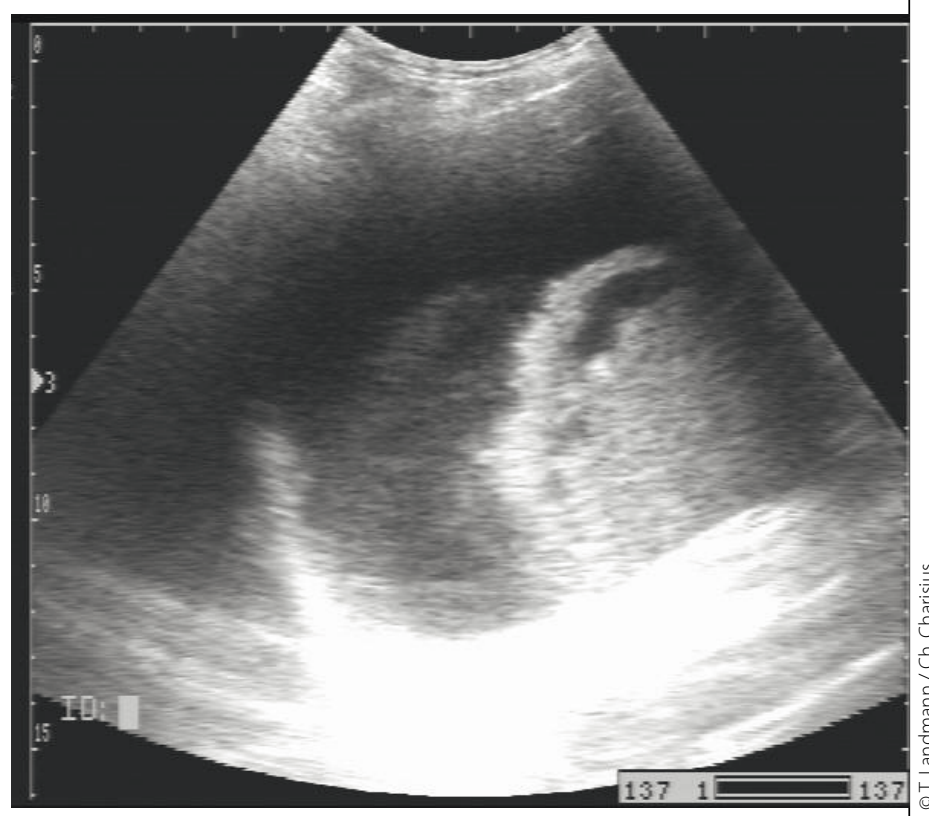

Pfeiffer'schen Drüsenfieber häufig ein massives Exanthem provoziert. Schwere Verläufe sind nicht ungewöhnlich, Milzkapselrisse bzw. Blutungen jedoch laut Literatur eher sehr selten. Sie sollten aber immer ausgeschlossen werden, sodass bei dieser Erkrankung eine zusätzliche abdominelle Sonografie unbedingt empfehlenswert erscheint.

Keywords: mononucleosis, splenic hemorrhage

- Dr. med. Thomas Landmann, Dr. med. Christoph Charisius, Gemeinschaftspraxis Innere/Allgemeinmedizin, Friedenstraße 6-8, D-50259 Pulheim

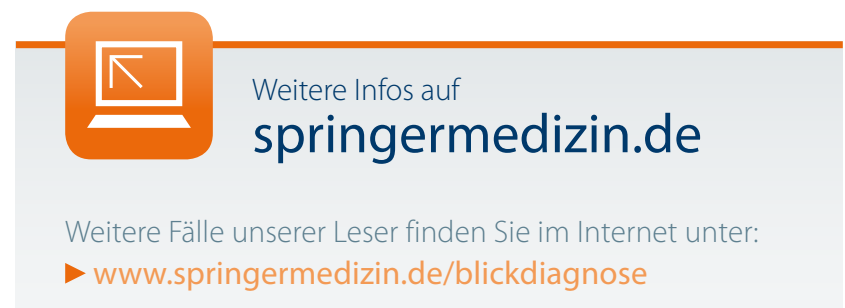

